Article

\title{
Explaining Social Media Adoption for a Business Purpose: An Application of the UTAUT Model
}

\author{
Wilert Puriwat ${ }^{1}$ and Suchart Tripopsakul ${ }^{2, *(D)}$ \\ 1 Chulalongkorn Business School, Chulalongkorn University, 254 Phayathai Road, Pathumwan, \\ Bangkok 10330, Thailand; wilert@cbs.chula.ac.th \\ 2 School of Entrepreneurship and Management, Bangkok University, 119 Rama IV Road, Prakanong, Klongtoey, \\ Bangkok 10110, Thailand \\ * Correspondence: suchart.t@bu.ac.th
}

Citation: Puriwat, W.; Tripopsakul, S. Explaining Social Media Adoption for a Business Purpose: An Application of the UTAUT Model. Sustainability 2021, 13, 2082. https:// doi.org/10.3390/su13042082

Academic Editor: Jose Ramon Saura

Received: 26 January 2021

Accepted: 12 February 2021

Published: 15 February 2021

Publisher's Note: MDPI stays neutral with regard to jurisdictional claims in published maps and institutional affiliations.

Copyright: (C) 2021 by the authors. Licensee MDPI, Basel, Switzerland. This article is an open access article distributed under the terms and conditions of the Creative Commons Attribution (CC BY) license (https:/ / creativecommons.org/licenses/by/ $4.0 /)$.

\begin{abstract}
Nowadays, the advance of the internet and mobile technologies have changed our daily life, not only in terms of consumption but in how business is done. Social media has been recognized as one of the potential online platforms for entrepreneurs especially in small and medium business establishments to cope with large corporations. This study aims to investigate elements affecting social media adoption for business purposes by adopting a well-known technology acceptance model - the unified theory of acceptance and use of technology (UTAUT). The data of 196 samples were collected via online questionnaires in Thailand using the structural equation modeling (SEM) technique employed to verify the proposed model with empirical data. The outcomes illustrate the performance and effort expectancy and social influence significantly influence behavior prospects to implement social media for business purposes. Facilitating conditions significantly contribute to affecting actual user behavior. Also, the authors investigated the moderating effect of all demographic and behavioral factors such as gender, age, daily spent time on social media, and entrepreneur status. The results of the one-way analysis of variance (ANOVA) analysis show that there are immense variances in the intention of social media behavior and use behavior due to age. Younger adults tend to be more adept with user behavior and behavioral intention more than older adults.
\end{abstract}

Keywords: social media; technology; adoption; the unified theory of acceptance and use of technology; Thailand

\section{Introduction}

The advancement in information and communication technologies (ICT) have made tremendous changes in people's life. Social media reach has expanded over the past few years. For businesses, social media can be utilized by entrepreneurs as platforms of business due to the requirement for minor technical knowledge. Social media is a growing widespread alternative platform for business purposes. It allows entrepreneurs to shift from one-to-one to many-to-many communication [1]. Social media features also avail inexpensive alternatives for tracking and targeting customers based on their online behaviors. Firms can employ social networking sites to market their goods, services, and brands in a very efficient way with a relatively lower cost [2].

According to the Global Digital Report in 2019, there were 4.388 billion worldwide internet users and there were 3.484 billion users of social media. In Thailand, there are 49 million mobile social media users, counting for $71 \%$ of total mobile users. In terms of daily time spent, Thai users are ranked the eighth in the world with $3.11 \mathrm{~h}$ per day whereas the global average is $2.16 \mathrm{~h} \mathrm{[3].} \mathrm{These} \mathrm{data} \mathrm{imply} \mathrm{the} \mathrm{potential} \mathrm{and} \mathrm{power} \mathrm{of} \mathrm{social}$ media not only for people's recreation but also for business purposes. Social media is an asset to entrepreneurs, enhancing their visibility and allowing them to penetrate new market segments. Currently, social media has become a crucial strategic movement for businesses. To cope with large-scale corporations, entrepreneurs can exploit the technology 
of social media as an important instrument to establish customer relationships and a quicker and cheaper communication other than face-to-face communication. Take Facebook, as it delivers a capability to focus on niche markets with lower expenditure than traditional media [4]. Facebook users are increasingly using the site to conduct commercial activities, by posting advertisements in groups and then buying or selling items from each other [5]. This type of social media usage is called "social media adoption for a business purpose" in this current study. In Thailand, social media can be realized as one of the effective channels for both full-time and part-time entrepreneurs to offer their products-both first and second-hand-into marketplaces. For example, numerous Facebook groups such as Rolex Market Thailand, Seiko Mania Market Thailand, PS4 market Thailand, and Samsung Galaxy Market Club Thailand allow customer-to-customer transactions. Facebook user members in particular Facebook groups can turn themselves into amateur merchants, semiprofessional sellers, or even professional ones. An individual level of social media usage for a business purpose has been realized as a popular trend to become an entrepreneur in this contemporary technology-mediated context. Although there have been previous studies examining the factors influencing social media adoption, using social media for a business purpose in terms of Consumers to Consumers (C2C) still needs empirical evidence to gain more understanding of the behavioral utilization of social media as a platform for business and to provide empirical evidence to the social media adoption literature in an individual level.

The study's goal is to assess the aspects affecting entrepreneurs' adoption of social media for business purposes by employing one of the well-known technology adoption models - the unified theory of acceptance and use of technology (UTAUT). The rest of the paper is classified as follows; the second section is the review of relevant literature. The third section entails a research methodology for the collection of data. The fourth section will discuss the main findings and analysis results. The fifth section entails the discussion and conclusion. Finally, the limitation and further research suggestions are in the sixth section.

\section{Literature Review}

\subsection{Social Media and Entrepreneurship}

Entrepreneurship is an important mechanism for nations' economic development. It has been deemed as one of the most efficient strategic movements for developing the economy into economic prosperity and sustaining competitive advantages [6]. On one hand, social media is evolving as an effective tool for businesses worldwide [7]. Previous pieces of research have exposed that social media empowers businesses to communicate with customers in a cost-efficient and immediate way [8]. Social media allows businesses to establish databases that help to provide a competitive advantage for businesses, which in turn leads to surging sales and enhancing company growth [9]. The continuous use and adoption of social media for business-related uses can inspire businesses' success and ultimately contribute to the development of the national economy [8]. Social media has been defined by many scholars [10]. One of the comprehensive definitions of social media is from [11], who established it as "a group of Internet-based applications that build on the ideological and technological foundations of Web 2.0, and that allow the creation and exchange of User Generated Content". Prior pieces of research established a correlation between the adoption of social media and the performance of businesses [12]. Social media provides businesses' capability to enhance numerous business actions such as transactions with partners, information sharing, communication managing, and supply chain management [13]. Previous research on social media adoption focused on developed countries and large corporations. Nevertheless, the generalization of these pieces of research findings need to be circumspect due to the several contextual differences between a country profile and business environmental context [2]. To the extent of our knowledge, there is limited research on the adoption of social media for business purposes, especially in efficiencydriven economies and small and medium business entrepreneurs. Thailand is one of the 
efficiency-driven economies with a high potential for usage of social media. However, further empirical studies to enhance the body of knowledge about social media adoption for business purposes at an individual level is still needed.

\subsection{Technology Adoption Models}

Social media is realized as a part of information technology (IT). Previous pieces of research concerning social media adoptions can be separated into two levels: individual and organizational levels. Numerous theories explain the adoption of technologies at both individual and organizational levels. Individually, theories are the theory of planned behavior (TPB) [14], the theory of reasoned action (TRA) [15], the technology acceptance model (TAM) [16], and the unified theory of acceptance and use of technology (UTAUT) [17] Organizationally, theories consist of the technology-organization-environment (TOE) framework [18] and the tri-core model [19]. Numerous factors are influencing the use and adoption of technology [12]. Ref. [20] stated that the UTAUT is one of the comprehensive models that can help effectively anticipate an adoption intention of technology-based applications and systems. UTAUT is one of the most extensively used models, proved to excel over other prevalent models. Recent studies by [21] extended an application of the UTAUT model by proposing a conceptual framework for predicting social media adoption as a communication tool and source of information for non-profit activities in non-urban communities. Ref. [21] suggested four key factors influencing intentions to adopt and use social media; namely, performance expectancy, effort expectancy, social conditions, and facilitating conditions. Further extension of the capability of technology adoption models like the UTAUT model could be useful to demonstrate the greater utility and practical value of UTAUT as a conceptual lens for behavioral modeling in contemporary technology-mediated environments [22]. Therefore, the authors decide to employ the UTAUT model in this study.

\subsection{Hypothesis Development}

Our conceptual proposed framework was adapted from the UTAUT model by [17]. According to the UTAUT model, there are four main aspects: effort and performance expectancies, social influence, and facilitating conditions. The first three factors determine the extent of usage intentions and behaviors. The facilitating conditions variable is used to determine user behavior. The expectancy of performance denotes the extent to which people think a system will assist them to achieve their jobs. Effort expectancy represents the extent of system usage-related ease. Social influence denotes how vital others believe the new system is in terms of the benefits of using it. Facilitating conditions denotes the extent to which one affirms that technical and organizational infrastructure is present to support the system usage. The moderating variable was adapted to be consistent with this study context and consisted of four factors: gender, age, time spent on social media, and entrepreneur status. The proposed conceptual framework of this study is illustrated in Figure 1.

The hypotheses are as follows:

H1. Performance Expectancy (PE) significantly influences Behavioral Intention (BI) to use social media for a business purpose.

H2. Effort Expectancy (EE) significantly influences Behavioral Intention (BI) to use social media for a business purpose.

H3. Social Influence (SI) significantly influences Behavioral Intention (BI) to use social media for a business purpose.

H4. Facilitating Conditions (FC) significantly influences Use Behavior (UB) to use social media for a business purpose.

H5. Behavioral Intention (BI) has a significantly positive effect on Use Behavior (UB). 
H6. The level of Performance Expectancy (PE), Effort Expectancy (EE), Social Influence (SI), Facilitating Conditions (FC), Behavioral Intention (BI), and Behavioral Intention (BI) are significantly different among demographic and behavioral variables (gender, age, time spent on social media, and entrepreneur status).

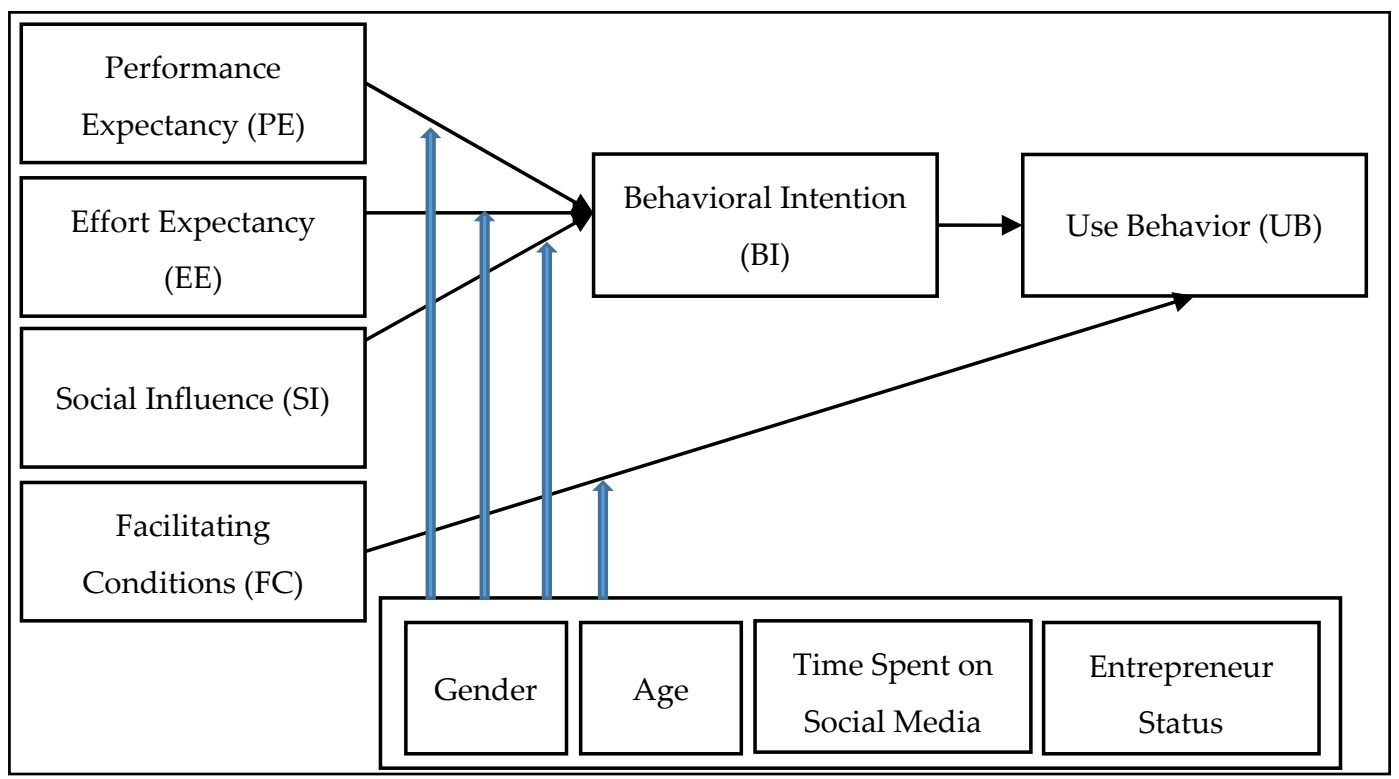

Figure 1. The proposed conceptual framework.

\section{Research Methodology}

\subsection{Research Design and Data Collection}

This study aimed to examine factors influencing social media adoption for business purposes by utilizing the UTAUT model. The quantitative research method was used. Structural equation modeling (SEM) was utilized to validate the proposed hypotheses and verify our suggested conceptual framework. According to [23], at least 150 participants were suggested for the sample size; however, other researchers $[24,25]$ suggested that a least 200 participants were needed for an acceptable SEM analysis-or at least 5 cases per parameter for uncomplicated SEM models. Since this study contained 25 observable variables, the minimum sample size was $25 \times 5=125$. The data were collected from a self-completed online questionnaire converted to a Google Form format. A convenience sampling technique was adopted in this study via an online questionnaire as the research instrument. The questionnaire link was distributed to those Facebook users who were in specific Facebook groups concerning buying and selling products in Thailand. Examples of Facebook groups that distributed the questionnaire link are Rolex Market Thailand (58.2K members), Seiko Mania Market Thailand (70.0K members), PlayStation 4 (PS4) market Thailand (155.1K members), and Samsung Galaxy Market Club Thailand (5.6K members). After data collection and screening, a total of 196 valid surveys were retained for analysis.

\subsection{Questionnaire Development}

The questionnaire contained two parts. The first section was concerned with demographic and behavioral information of respondents. The second section was concerned with measurement items according to the proposed model. The entirety of measurement items in this study were taken and modified from previous studies by $[17,26,27]$. The items were gauged per a five-point Likert scale ranging from strongly disagree (1) to strongly agree (5). In the proposed model, the independent variables consisted of four constructs: performance expectancy (PE, five items), effort expectancy (EE, four items), social influence 
(SI, four items), and facilitating conditions (FC, four items). Dependent variables were composed of two constructs: behavioral intention (BI, four items) and use behavior (UB, four items). In total, there were 25 items of measurement, and the details of every construct are available in Table 1.

Table 1. The details of constructs, items, and observed variables in the study.

\begin{tabular}{|c|c|c|}
\hline Constructs & Items & Observed Variables \\
\hline \multirow{5}{*}{ Performance Expectancy (PE) } & PE1 & Social media are useful for running your business. \\
\hline & PE2 & Using online social media will make you more profitable in doing business. \\
\hline & PE3 & Using social media can increase your chances of achieving your business goals. \\
\hline & PE4 & $\begin{array}{l}\text { Using social media can help improve the quality of your existing } \\
\text { business information. }\end{array}$ \\
\hline & PE5 & $\begin{array}{l}\text { Using online social media will allow you to spend less time achieving your } \\
\text { business goals. }\end{array}$ \\
\hline \multirow{4}{*}{ Effort Expectancy (EE) } & EE1 & Learning to use online social media to do business is easy for you. \\
\hline & EE2 & You expect the use of social media to do business is clear and understandable. \\
\hline & EE3 & It's easy for you to become proficient in using social media to do business. \\
\hline & EE4 & Using online social media will help you achieve faster trading. \\
\hline \multirow{4}{*}{ Social Influence (SI) } & SI1 & $\begin{array}{l}\text { People who are important to me think that I should use social media for a } \\
\text { business purpose }\end{array}$ \\
\hline & SI2 & $\begin{array}{l}\text { People who influence my behavior think that I should use social media for a } \\
\text { business purpose }\end{array}$ \\
\hline & SI3 & $\begin{array}{l}\text { People whose opinions that I value prefer that I use social media for a } \\
\text { business purpose }\end{array}$ \\
\hline & SI 4 & $\begin{array}{l}\text { People around me consider it is appropriate to use social media for a } \\
\text { business purpose }\end{array}$ \\
\hline \multirow{4}{*}{ Facilitating Conditions (FC) } & FC1 & You have the necessary knowledge to use online social media to do business. \\
\hline & FC2 & You have acquaintances who can help you when faced with social media issues. \\
\hline & FC3 & You have the resources you need to use online social media to do business. \\
\hline & FC4 & Social media work well with other platforms you use. \\
\hline \multirow{4}{*}{ Behavioral Intention (BI) } & BI1 & You are determined to use social media to do business in the next month. \\
\hline & BI2 & $\begin{array}{l}\text { You expect that you should use online social media to do business in the } \\
\text { next month. }\end{array}$ \\
\hline & BI3 & You plan to use social media to do business in the next month. \\
\hline & BI4 & You will use social media when you have a business need. \\
\hline \multirow{4}{*}{ Use Behavior (UB) } & UB1 & You often use social media for doing your business. \\
\hline & UB2 & You have been using social media regularly to communicate with stakeholders. \\
\hline & UB3 & You have been using social media in my daily life for business purposes. \\
\hline & UB4 & You take advantage of online social networks to do business. \\
\hline
\end{tabular}

\section{Results and Discussions}

\subsection{Descriptive Statistic Results}

The majority of respondents were females $(58.7 \%)$ working in corporate fields $(41.3 \%)$ with more than USD 1837 monthly salary $(42.9 \%)$. The majority of the respondents $(23.0 \%)$ were aged between 36 to 40 years with above an undergraduate education level (57.1\%), allocating more than four hours (50.0\%) in social media daily. Moreover, the most popular time spent on social media was between $18.01-24.00 \mathrm{pm}(74.0 \%)$. The demographic profiles are detailed in Table 2. 
Table 2. Descriptive statistics.

\begin{tabular}{|c|c|c|c|}
\hline Item & Description & Sample & $\%$ \\
\hline \multirow{2}{*}{ Gender } & Male & 81 & 41.3 \\
\hline & Female & 115 & 58.7 \\
\hline \multirow{9}{*}{ Age } & $20-25$ & 20 & 10.2 \\
\hline & $26-30$ & 32 & 16.3 \\
\hline & $31-35$ & 22 & 11.2 \\
\hline & $36-40$ & 45 & 23.0 \\
\hline & $41-45$ & 40 & 20.4 \\
\hline & $46-50$ & 17 & 8.7 \\
\hline & $51-55$ & 12 & 6.1 \\
\hline & $55-60$ & 4 & 2.0 \\
\hline & Above 60 & 4 & 2.0 \\
\hline \multirow{3}{*}{ Marital Status } & Single & 102 & 52.0 \\
\hline & Married & 88 & 44.9 \\
\hline & Other & 6 & 3.1 \\
\hline \multirow{3}{*}{ Education } & Below Undergraduate & 5 & 2.6 \\
\hline & Undergraduate & 112 & 57.1 \\
\hline & Postgraduate & 79 & 40.3 \\
\hline \multirow{4}{*}{ Occupation } & Student & 23 & 11.7 \\
\hline & Government Officer & 38 & 19.4 \\
\hline & Private Company Officer & 81 & 41.3 \\
\hline & Entrepreneur & 54 & 27.6 \\
\hline \multirow{4}{*}{ Income (USD) } & Less than 501 & 23 & 11.7 \\
\hline & 501-1169 & 42 & 21.4 \\
\hline & 1170-1837 & 47 & 24.0 \\
\hline & More than 1837 & 84 & 42.9 \\
\hline \multirow{4}{*}{$\begin{array}{l}\text { Daily Time Spent on } \\
\text { Social Media }\end{array}$} & Less than one hour & - & - \\
\hline & One hour-two hours & 34 & 17.3 \\
\hline & Three hours-four hours & 64 & 32.7 \\
\hline & More than four hours & 98 & 50.0 \\
\hline \multirow{4}{*}{$\begin{array}{l}\text { Favorite Time to Use } \\
\text { Social Media }\end{array}$} & $06.01-12.00$ & 9 & 4.6 \\
\hline & $12.01-18.00$ & 41 & 20.9 \\
\hline & $18.01-24.00$ & 145 & 74.0 \\
\hline & $24.01-06.00$ & 1 & 0.5 \\
\hline
\end{tabular}

Note: $\mathrm{N}=196$; missing data not shown and calculated in the table; 1 USD $=29.95$ Baht.

The authors also asked respondents to rate the degree of usage frequency via telecommunication devices and their perception of how important each social media application was. A five-point Likert scale was utilized and ranged from " $1=$ Never/not at all important" to " 5 = Always/extremely Important". Based on those questions, Facebook (Mean = 4.32) and Line (Mean $=4.24$ ) were the two most important applications for doing business as online platforms, and mobile devices (Mean $=4.65$ ) were the most frequently used devices for using social media apart from other devices. The mean scores and interpretation are detailed in Table 3. 
Table 3. The result of mean scores and interpretation.

\begin{tabular}{|c|c|c|c|c|}
\hline Questions & Items & Mean & SD & Interpretation \\
\hline \multirow{4}{*}{$\begin{array}{c}\text { In the past three months, how frequently } \\
\text { do you use social media through the } \\
\text { following devices? }\end{array}$} & Smartphone/Mobile & 4.65 & 0.67 & Always \\
\hline & Laptop/Notebook & 3.07 & 1.22 & Sometimes \\
\hline & Desktop/PC & 2.10 & 1.31 & Rarely \\
\hline & Others such as Tablets & 2.26 & 1.24 & Rarely \\
\hline \multirow{7}{*}{$\begin{array}{l}\text { From the following online social } \\
\text { networking applications, could you rate } \\
\text { how useful these online applications for a } \\
\text { business purpose? }\end{array}$} & Facebook & 4.32 & 0.75 & Extremely important \\
\hline & Facebook Messenger & 3.36 & 1.12 & Moderately important \\
\hline & Instagram & 3.49 & 1.19 & Very important \\
\hline & YouTube & 3.62 & 0.95 & Very important \\
\hline & LINE & 4.24 & 0.82 & Very important \\
\hline & WhatsApp & 2.04 & 1.08 & Slightly important \\
\hline & Twitter & 2.40 & 1.11 & Slightly important \\
\hline
\end{tabular}

For the hypothesis testing, the authors firstly tested a model of measurement via confirmatory factor analysis (CFA). According to [28], construct validity was how accurate a set of observed variables truly represent the latent variables to be measured theoretically. Convergent and discriminant validities were examined through criteria postulated by [28] The outcomes confirmed a total of 23 items which include PE (five items), EE (four items), SI (four items), FC (four items), BI (three items), and UB (three items). Two items were deleted since the standardized item loading was less than 0.5 as suggested by [29]. Cronbach's outcome for the instrument ranged between 0.849-0.912. The outcomes of the model of measurement are illustrated in Tables 4 and 5.

Table 4. Reliability and validity of constructs.

\begin{tabular}{|c|c|c|c|c|c|}
\hline Construct & Item Code & Item Loadings & CR & AVE & Cronbach's Alpha \\
\hline \multirow{5}{*}{ Performance Expectancy (PE) } & PE1 & 0.772 & \multirow{5}{*}{0.896} & \multirow{5}{*}{0.636} & \multirow{5}{*}{0.897} \\
\hline & PE2 & $0.845^{* * *}$ & & & \\
\hline & PE3 & $0.894^{* * *}$ & & & \\
\hline & PE4 & $0.799 * * *$ & & & \\
\hline & PE5 & $0.658 * * *$ & & & \\
\hline \multirow{4}{*}{ Effort Expectancy (EE) } & EE1 & 0.791 & \multirow{4}{*}{0.853} & \multirow{4}{*}{0.592} & \multirow{4}{*}{0.853} \\
\hline & EE2 & $0.803^{* * *}$ & & & \\
\hline & EE3 & $0.755^{* * *}$ & & & \\
\hline & EE4 & $0.727^{* * *}$ & & & \\
\hline \multirow{4}{*}{ Social Influence (SI) } & SI1 & 0.839 & \multirow{4}{*}{0.823} & \multirow{4}{*}{0.540} & \multirow{4}{*}{0.821} \\
\hline & SI2 & $0.743^{* * *}$ & & & \\
\hline & SI3 & $0.682^{* * *}$ & & & \\
\hline & SI4 & $0.664^{* * *}$ & & & \\
\hline \multirow{4}{*}{ Facilitating Conditions (FC) } & FC1 & 0.741 & \multirow{4}{*}{0.850} & \multirow{4}{*}{0.586} & \multirow{4}{*}{0.854} \\
\hline & FC2 & $0.732 * * *$ & & & \\
\hline & FC3 & $0.782^{* * *}$ & & & \\
\hline & FC4 & $0.805^{* * *}$ & & & \\
\hline
\end{tabular}


Table 4. Cont.

\begin{tabular}{|c|c|c|c|c|c|}
\hline Construct & Item Code & Item Loadings & CR & AVE & Cronbach's Alpha \\
\hline \multirow{4}{*}{ Behavioral Intention (BI) } & BI1 & 0.954 & \multirow{4}{*}{0.974} & \multirow{4}{*}{0.925} & \multirow{4}{*}{0.878} \\
\hline & BI2 & $0.980^{* * *}$ & & & \\
\hline & $\mathrm{BI} 3$ & $0.951^{* * *}$ & & & \\
\hline & BI4 & 0.315 (Deleted) & & & \\
\hline \multirow{4}{*}{ Use Behavior (UB) } & UB1 & 0.903 & \multirow{4}{*}{0.930} & \multirow{4}{*}{0.815} & \multirow{4}{*}{0.853} \\
\hline & UB2 & $0.939^{* * *}$ & & & \\
\hline & UB3 & 0.373 (Deleted) & & & \\
\hline & UB4 & $0.865^{* * *}$ & & & \\
\hline
\end{tabular}

Notes: PE1, EE1, SI1, FC1, BI1, and UB1 are fixed parameters; ${ }^{* * *} p<0.001$.

Table 5. Discriminant validity.

\begin{tabular}{ccccccc}
\hline & PE & EE & SI & FC & BI & UB \\
\hline PE & $\mathbf{0 . 7 9 8}$ & & & & & \\
\hline EE & 0.601 & $\mathbf{0 . 7 7 0}$ & & & & \\
\hline SI & 0.584 & 0.554 & $\mathbf{0 . 7 3 5}$ & & & \\
\hline FC & 0.531 & 0.654 & 0.589 & $\mathbf{0 . 7 6 6}$ & & \\
\hline BI & 0.574 & 0.523 & 0.583 & 0.596 & $\mathbf{0 . 9 6 2}$ & \\
\hline UB & 0.614 & 0.551 & 0.525 & 0.604 & 0.566 & $\mathbf{0 . 9 0 3}$
\end{tabular}

Notes: Bold diagonal elements are the square root of Average Variance Extracted (AVE) for each construct. Off-diagonal elements are the correlations between constructs.

As shown in Table 4, the analysis of the measurement with six constructs resulted in a satisfied model fit (Chi-square $=522.861 ; \mathrm{df}=260 ; \mathrm{CMIN} / \mathrm{df}=2.011 ; \mathrm{GFI}=0.912$; $\mathrm{NFI}=0.923 ; \mathrm{TLI}=0.920 ; \mathrm{CFI}=0.928 ; \mathrm{RMSEA}=0.039)$. The validity indicators of convergent are standardized factor loadings, Average Variance Extracted (AVE), and Composite Reliability (CR) [30]. All the achieved and recommended measures and values by [28] (AVE $>0.5$ and CR $>0.7$ ) represented convergent validity acceptance. Table 5 illustrates the test for the validity of the discriminant. The validity of the discriminant was attained since AVE's square root of every construct exceeded their corresponding inter-construct correlation estimates.

\subsection{Structural Model and Hypotheses Testing}

Following the evaluation of the measurement model, the upcoming step was to formulate the structural model. The results of the hypothesized path model illustrated in Figure 2.

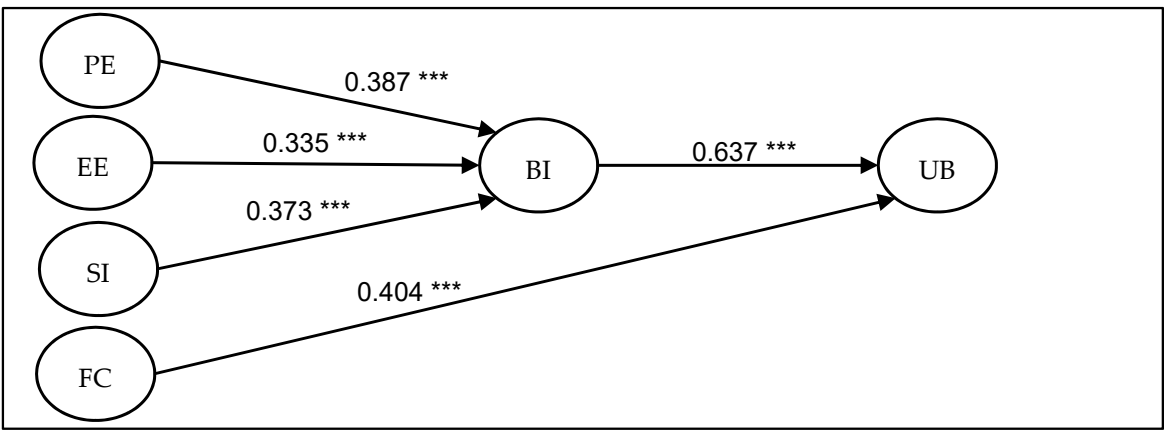

Figure 2. Structural equation modeling (SEM) result. Notes: ${ }^{* *} p<0.001$.Fit indices: Chi-square $=$ 495.792; $\mathrm{df}=264 ; \mathrm{CMIN} / \mathrm{df}=1.878 ; \mathrm{GFI}=0.935 ; \mathrm{NFI}=0.932 ; \mathrm{TLI}=0.923 ; \mathrm{CFI}=0.935 ; \mathrm{RMSEA}=0.034$. 
The findings of the hypothesized path model demonstrated a fit-to-data adequate model $($ Chi-square $=495.792 ; \mathrm{df}=264 ; \mathrm{CMIN} / \mathrm{df}=1.878 ; \mathrm{GFI}=0.935 ; \mathrm{NFI}=0.932$; $\mathrm{TLI}=0.923 ; \mathrm{CFI}=0.935 ; \mathrm{RMSEA}=0.034)$. The residual variances for the latent variables behavioral intention and use behavior were 0.45 and 0.54 . Table 6 's hypothesis testing results showed the three hypotheses' significance, respectively.

Table 6. Structural parameter estimates.

\begin{tabular}{cccc}
\hline Hypotheses & Relationship & Estimate (b) & Result \\
\hline $\mathrm{H} 1$ & $\mathrm{PE} \rightarrow \mathrm{BI}$ & $0.387^{* * *}$ & Accepted \\
\hline $\mathrm{H} 2$ & $\mathrm{EE} \rightarrow \mathrm{BI}$ & $0.335^{* * *}$ & Accepted \\
\hline $\mathrm{H} 3$ & $\mathrm{SI} \rightarrow \mathrm{BI}$ & $0.373^{* * *}$ & Accepted \\
\hline $\mathrm{H} 4$ & $\mathrm{FC} \rightarrow \mathrm{UB}$ & $0.404^{* * *}$ & Accepted \\
\hline $\mathrm{H} 5$ & $\mathrm{BI} \rightarrow \mathrm{UB}$ & $0.637^{* * *}$ & Accepted \\
\hline
\end{tabular}

Notes: $R 2$ (Behavioral intention) $=0.45 ; R 2$ (Use behavior) $=0.54 ;{ }^{* * *} p<0.001$.

The correlation between performance expectancy (PE) and behavioral intention (BI) was supported $(\mathrm{H} 1: \mathrm{b}=0.387, t$-value $=4.796$, sig $<0.001)$. $\mathrm{H} 2$ postulated that effort expectancy (EE) significantly positively impacts behavioral intention (BI), which was also supported $(\mathrm{H} 2: \mathrm{b}=0.335, t$-value $=4.230$, sig < 0.001$)$. H3 postulated that social influence (SI) had significant positive impacts on behavioral intention (BI) which was also supported $(\mathrm{H} 3: \mathrm{b}=0.373, t$-value $=4.569, \mathrm{sig}<0.001) . \mathrm{H} 4$ postulated that facilitating conditions $(\mathrm{FC})$ significantly positively impacts use behavior (UB) which was also supported (H4: $b=0.404$, $t$-value $=6.211, \mathrm{sig}<0.001)$. Lastly, behavioral intention (BI) had a significant positive effect on user behavior (UB) $(\mathrm{H} 5: \mathrm{b}=0.637, t$-value $=7.748$, sig $<0.001)$.

To test the effect of moderation of all demographic and behavior variables, namely gender, age, time spent on social media, and entrepreneur status on the levels of four exogenous (PE, EE, SI, and FC) and two endogenous variables (BI and UB), the authors employed the one-way ANOVA technique to examine each moderate variable with all constructs in the model. The one-way ANOVA results found that the levels of all six constructs were significantly different among age groups, and the level of two endogenous variables (BI and $\mathrm{UB})$ were significantly different among entrepreneur status. Therefore, Hypothesis 6 (H6) was supported. The results of one-way ANOVA analysis are illustrated in Table 7.

Table 7. The results of the one-way ANOVA analysis.

\begin{tabular}{|c|c|c|c|c|c|c|}
\hline \multicolumn{7}{|c|}{ ANOVA } \\
\hline & & Sum of Squares & df & Mean Square & $F$ & Sig. \\
\hline \multirow{3}{*}{$\mathrm{BI} \times \mathrm{AGE}$} & Between Groups & 5.129 & 7 & 0.733 & 2.494 & 0.018 \\
\hline & Within Groups & 227.253 & 188 & 1.209 & - & - \\
\hline & Total & 232.381 & 195 & - & - & - \\
\hline \multirow{3}{*}{$\mathrm{UB} \times \mathrm{AGE}$} & Between Groups & 30.056 & 7 & 4.294 & 4.231 & 0.000 \\
\hline & Within Groups & 181.212 & 188 & 0.964 & - & - \\
\hline & Total & 211.269 & 195 & - & - & - \\
\hline \multirow{3}{*}{$\mathrm{PE} \times \mathrm{AGE}$} & Between Groups & 8.634 & 7 & 1.233 & 3.860 & 0.001 \\
\hline & Within Groups & 98.580 & 188 & 0.524 & - & - \\
\hline & Total & 107.214 & 195 & - & - & \\
\hline \multirow{3}{*}{$\mathrm{EE} \times \mathrm{AGE}$} & Between Groups & 7.909 & 7 & 1.130 & 2.192 & 0.037 \\
\hline & Within Groups & 96.902 & 188 & 0.515 & - & - \\
\hline & Total & 104.811 & 195 & - & - & - \\
\hline
\end{tabular}


Table 7. Cont

\begin{tabular}{|c|c|c|c|c|c|c|}
\hline \multicolumn{7}{|c|}{ ANOVA } \\
\hline \multirow{3}{*}{$\mathrm{SI} \times \mathrm{AGE}$} & Between Groups & 7.588 & 7 & 1.084 & 4.421 & 0.000 \\
\hline & Within Groups & 100.502 & 188 & 0.535 & - & - \\
\hline & Total & 108.090 & 195 & - & - & \\
\hline \multirow{3}{*}{$\mathrm{FC} \times \mathrm{AGE}$} & Between Groups & 15.869 & 7 & 2.267 & 4.166 & 0.000 \\
\hline & Within Groups & 102.316 & 188 & 0.544 & - & - \\
\hline & Total & 118.185 & 195 & - & - & - \\
\hline \multirow{3}{*}{$\mathrm{BI} \times \mathrm{EN}$} & Between Groups & 30.681 & 1 & 30.681 & 29.510 & 0.000 \\
\hline & Within Groups & 201.700 & 194 & 1.040 & - & - \\
\hline & Total & 232.381 & 195 & - & - & - \\
\hline \multirow{3}{*}{$\mathrm{UB} \times \mathrm{EN}$} & Between Groups & 20.603 & 1 & 20.603 & 20.963 & 0.000 \\
\hline & Within Groups & 190.666 & 194 & 0.983 & - & - \\
\hline & Total & 211.269 & 195 & - & - & - \\
\hline
\end{tabular}

Note: Only significantly statistical results of the one-way ANOVA are shown in the table. AGE = Age range; BI = Behavioral intention; $\mathrm{UB}=$ Use behavior; $\mathrm{PE}=$ Performance expectancy; $\mathrm{EE}=$ Effort expectancy; SI = Social influence; FC = Facilitating conditions; EN = Entrepreneur status.

\section{Discussion and Conclusions}

Nowadays, social media plays more and more important roles in business, allowing an individual to become an entrepreneur or do businesses easier than brick-and-mortar businesses. This study investigated factors influencing social media adoption for business purposes in Thailand. Per the UTUAT model, the empirical data of 196 Thai respondents exhibited that performance and effort expectancies and social influence have a positive and impactful effect on behavior intention to adopt social media for business purposes among Thai people, and facilitating conditions also have a significant and positive influence on user behavior. These findings are in agreement with the previous research by [8]. When considering factor loadings of each construct on behavior intentions, we realized that performance expectancy had the strongest effect on behavior intention. The outcome was consistent with the previous research by [31] which found that performance expectancy maintained the most dominant predictability towards behavioral intention compared with social influence and effort expectancy. This could be translated into people already knowing that social media is useful for business purposes and using social media as an alternative business platform will enhance their business performance. Our results also reveal that Facebook and Line applications are ranked the first and second most useful applications for doing business according to the respondents' opinions. Effort expectancy was ranked as the second most vital aspect influencing behavioral intention. This finding is consistent with [26], who showed that effort expectancy had a strong influence on behavioral intention and the complicated online system would discourage people from adopting it. Compared with other online platforms, social media seem to be the platform with the least effort required and the most user-friendly application for business purposes since people can get used to social media applications such as Facebook and Line easily, as they already use those social media applications for other purposes such as contacting and socializing with their friends and family. Results also indicated that social influence impacts behavioral intention. This finding is in the line with previous studies by [32], illustrating social influence's significant role in online application adoptions. An earlier study by [17] demonstrates that facilitating conditions directly affect user behavior. Our finding is consistent with [33], who claimed that facilitating conditions in Facebook usage positively influenced the adoption of social media. The level of behavioral intention and use behavior to adopt social media for business purposes are moderated by age. This result is reconfirmed and align with [17]. Younger adults tend to maintain a higher level of behavioral 
intention and use behavior to adopt social media. This phenomenon can be interpreted by the fact that younger adults seem to get used to social media and possess a higher information technology skill than older adults. This study enhances the already-present research knowledge of the UTAUT model since there are very limited pieces of research on social media adoption for business purposes, especially in efficiency-driven economy contexts such as in Thailand.

\subsection{Theoretical Implications}

This study contributes to both theory and social media adoption literature in two aspects. Firstly, the authors empirically examined the relationship between three factors of the UTAUT model behavioral intentions with regard to social media adoption for a business purpose in the $\mathrm{C} 2 \mathrm{C}$ context like "buying and selling transactions in Facebook groups. This study, therefore, contributes to the literature by providing empirical evidence that "performance expectancy", "effort expectancy", and "social influence" are the factors affecting individual behavioral intention. Secondly, this study expands the applicability of the UTAUT model by using it to explain the phenomenon of amateur and part-time entrepreneurs in Thailand. Part-time entrepreneurship is often the first step towards full-time entrepreneurship [34]. An advantage of social media and its usage popularity empowers users to simultaneously become both buyers and sellers. With the low cost of investment required, social media open a room for anyone who possesses the inspiration to become an entrepreneur with affordable cost of investment.

\subsection{Practical and Managerial Implications}

Social media has become a more predominant platform and offers a good chance for people to easily start their businesses. Our study provides practical and managerial implications for policymakers and practitioners. Firstly, working a second job is a useful option for coping with the global economic recession due to the COVID-19 pandemic both for the individual and for a nation's economy. Promoting social media for business purposes and providing necessary skills to implement selling products via social media platforms can be considered as one of the strategic plans for national SMEs promotion agencies as a result of the cost-efficiency and the low technology skill required. Policymakers should develop tailor-made social media for a business program provided through the government's vocational skills training centers around the country. Secondly, educational institutions at all levels should rethink and redesign their curriculums by adding social media for business programs. Although the social media usage statistic [35] showed that the younger generation spends more time on social media and seems to get used to technology applications faster than older generations, lacking business experiences and skills may cause social media use to be ineffective when selling or promoting their products. Therefore, enhancing both technology and business skill through well-customized programs will strengthen the entrepreneurial spirit and capability of young generations which subsequently lead to the sustainability of nations' economic and social development.

\section{Limitation and Research Recommendation}

Although this study provided an understanding of the influencing aspects of the adoption of social media for business purposes, our study has limitations. Firstly, data collection was limited to Thailand; the findings should be meticulously generalized for other countries. Future studies can explore social media adoption across different cultures. Secondly, whereas a survey method with a quantitative nature was picked for this study, an in-depth interview should provide further insights about social media adoption. Moreover, future pieces of research could comparatively study among other technology acceptant models for both individual and organizational levels such as TAM, TOE, and Diffusion of Innovation (DOI) models, to enrich understanding about social media adoption for business purposes.

Author Contributions: W.P. conceptualized and participated study design, coordinated data collection, carried out the initial analyses, drafted the initial manuscript, and read and approved the 
manuscript. S.T. participated in study design, guided the methodology coordinated and supervised data collection and analyses, reviewed and edited manuscript. Both authors read and approved the manuscript as submitted and agree to be accountable for all aspects of the work. All authors have read and agreed to the published version of the manuscript.

Funding: This research received no external funding.

Institutional Review Board Statement: This study was carried out through the approval of the Ethics Committee for Human Research, Bangkok University (Reference no. 416312003), in accordance with the Declaration of Helsinki.

Informed Consent Statement: Informed consent was obtained from all subjects involved in the study.

Data Availability Statement: The datasets generated during and/or analyzed during the current study are not publicly available due to IRB stipulations but are available from the corresponding author on reasonable request.

Conflicts of Interest: The authors declare no conflict of interest.

\section{References}

1. Siamagka, N.-T.; Christodoulides, G.; Michaelidou, N.; Valvi, A. Determinants of social media adoption by B2B organizations. Ind. Mark. Manag. 2015, 51, 89-99. [CrossRef]

2. Ahmad, S.Z.; Abu Bakar, A.R.; Ahmad, N. Social media adoption and its impact on firm performance: The case of the UAE. Int. J. Entrep. Behav. Res. 2019, 25, 84-111. [CrossRef]

3. Puriwat, W.; Tripopsakul, S. We Are Social; We Are Social Inc.: New York, NY, USA, 2019.

4. Gavino, M.C.; Williams, D.E.; Jacobson, D.; Smith, I. Latino entrepreneurs and social media adoption: Personal and business social network platforms. Manag. Res. Rev. 2019, 42, 469-494. [CrossRef]

5. Chen, J.V.; Su, B.-C.; Widjaja, A.E. Facebook C2C social commerce: A study of online impulse buying. Decis. Support Syst. 2016, 83, 57-69. [CrossRef]

6. Acs, Z.J. Entrepreneurship and economic development: The valley of backwardness. Ann. Innov. Entrep. 2010, 1, 5641. [CrossRef]

7. Veldeman, C.; Van Praet, E.; Mechant, P. Social Media Adoption in Business-to-Business: IT and Industrial Companies Compared. Int. J. Bus. Commun. 2015, 54, 283-305. [CrossRef]

8. Nawi, N.B.C.; Al Mamun, A.; Nasir, N.A.B.M.; Shokery, N.M.B.A.H.; Raston, N.B.A.; Fazal, S.A. Acceptance and usage of social media as a platform among student entrepreneurs. J. Small Bus. Enterp. Dev. 2017, 24, 375-393. [CrossRef]

9. Jagongo, A.; Kinyua, C. The social media and entrepreneurship growth. Int. J. Humanit. Soc. Sci. 2013, 310, $213-227$.

10. Kietzmann, J.H.; Hermkens, K.; McCarthy, I.P.; Silvestre, B.S. Social media? Get serious! Understanding the functional building blocks of social media. Bus. Horiz. 2011, 54, 241-251. [CrossRef]

11. Kaplan, A.M.; Haenlein, M. Users of the world, unite! The challenges and opportunities of Social Media. Bus. Horiz. 2010, 53, 59-68. [CrossRef]

12. Alsharji, A.; Ahmad, S.Z.; Abu Bakar, A.R. Understanding social media adoption in SMEs. J. Entrep. Emerg. Econ. 2018, 10, 302-328. [CrossRef]

13. Humphrey, J. Opportunities for SMEs in Developing Countries to Upgrade in a Global Economy; International Labour Organization: Geneva, Switzerland, 2003.

14. Ajzen, I. The theory of planned behavior. Organ. Behav. Hum. Decis. Process. 1991, 50, 179-211. [CrossRef]

15. Fishbein, M.; Ajzen, I. Belief, Attitude, Intention, and Behavior: An Introduction to Theory and Research; Adison-Wesley: Reading, MA, USA, 1975. [CrossRef]

16. Davis, F.D. Perceived Usefulness, Perceived Ease of Use, and User Acceptance of Information Technology. MIS Q. 1989, 13, 319-340. [CrossRef]

17. Venkatesh, V.; Morris, M.G. Davis User Acceptance of Information Technology: Toward a Unified View. MIS Q. 2003, 27, 425. [CrossRef]

18. Tornatzky, L.G.; Fleischer, M.; Chakrabarti, A.K. Processes of Technological Innovation; Lexington Books: Lexington, KY, USA, 1990.

19. Swanson, E.B. Information Systems Innovation among Organizations. Manag. Sci. 1994, 40, 1069-1092. [CrossRef]

20. Gupta, K.P.; Manrai, R.; Goel, U. Factors influencing adoption of payments banks by Indian customers: Extending UTAUT with perceived credibility. J. Asia Bus. Stud. 2019, 13, 173-195. [CrossRef]

21. Lim, W.M.; Lim, A.L.; Phang, C.S.C. Toward a conceptual framework for social media adoption by non-urban communities for non-profit activities: Insights from an integration of grand theories of technology acceptance. Australas. J. Inf. Syst. 2019, 23. [CrossRef]

22. Lim, W.M. Dialectic Antidotes to Critics of the Technology Acceptance Model: Conceptual, Methodological, and Replication Treatments for Behavioural Modelling in Technology-Mediated Environments. Australas. J. Inf. Syst. 2018, 22. [CrossRef]

23. Anderson, J.C.; Gerbing, D.W. Structural equation modeling in practice: A review and recommended two-step approach. Psychol. Bull. 1988, 103, 411-423. [CrossRef] 
24. Bentler, P.M.; Chou, C.-P. Practical Issues in Structural Modeling. Sociol. Methods Res. 1987, 16, 78-117. [CrossRef]

25. Kline, R.B. Principles and Practice of Structural Equation Modeling; Guilford: New York, NY, USA, 2011.

26. Chua, P.Y.; Rezaei, S.; Gu, M.-L.; Oh, Y.; Jambulingam, M. Elucidating social networking apps decisions. Nankai Bus. Rev. Int. 2018, 9, 118-142. [CrossRef]

27. Martín, H.S.; Herrero, Á. Influence of the user's psychological factors on the online purchase intention in rural tourism: Integrating innovativeness to the UTAUT framework. Tour. Manag. 2012, 33, 341-350. [CrossRef]

28. Hair, J.F.; Black, W.C.; Babin, B.J.; Anderson, R.E.; Tatham, R.L. Multivariate Data Analysis: Global Edition, 7th ed.; Pearson Education: New York, NY, USA, 2010; Volume 5, pp. 629-686.

29. Bagozzi, R.P.; Yi, Y. On the evaluation of structural equation models. J. Acad. Mark. Sci. 1988, 16, 74-94. [CrossRef]

30. Fornell, C.; Larcker, D.F. Evaluating Structural Equation Models with Unobservable Variables and Measurement Error. J. Mark. Res. 1981, 18, 39. [CrossRef]

31. Almatari, A.Y.; Iahad, N.A.; Balaid, A.S. Factors influencing students' intention to use M-learning. J. Inf. Syst. Res. Innov. 2013, $5,1-8$.

32. Taylor, D.G.; Voelker, T.A.; Pentina, I. Mobile Application Adoption by Young Adults: A Social Network Perspec-tive. Int. J. Mob. Mark. 2011, 6, 60-70.

33. EscobarRodriguez, T.; Carvajaltrujillo, E. Online purchasing tickets for low cost carriers: An application of the unified theory of acceptance and use of technology (UTAUT) model. Tour. Manag. 2014, 43, 70-88. [CrossRef]

34. Block, J.H.; Landgraf, A. Transition from part-time entrepreneurship to full-time entrepreneurship: The role of financial and non-financial motives. Int. Entrep. Manag. J. 2016, 12, 259-282. [CrossRef]

35. Chaffey, D. Global Social Media Research Summary August 2020. 2020. Available online: https:/ /www.smartinsights.com/ social-media-marketing/social-media-strategy/new-global-social-media-research/ (accessed on 9 February 2021). 